\title{
Metasomatotrophic Diabetes and Its Induction: Basal Insulin Secretion and Insulin Release Responses to Glucose, Glucagon, Arginine and Meals
}

\author{
J. Pierluissi and J. Campbell \\ Department of Physiology, University of Toronto, Toronto, Ontario, Canada
}

\begin{abstract}
Summary. Growth hormone treatment produced somatotrophic diabetes, with hyperglycaemia, polyuria, glycosuria and elevation in serum non-esterified fatty acids (NEFA) in dogs. Early in this diabetes, fasting serum immunoreactive insulin (IRI) rose 20fold, the insulin/glucose (I/G) ratio rose 10 -fold and in response to glucose infusion, the rise in IRI was twice the normal. In the latter half of the continued growth hormone treatment, the intensity of the diabetes increased, serum IRI declined to the normal level and the $\mathrm{I} / \mathrm{G}$ ratio became subnormal. Late in the treatment, following glucose infusion, there was no change in serum IRI, no fall in NEFA and further depression of glucose tolerance. In metasomatotrophic diabetes, in which hyperglycaemia, glycosuria and high NEFA level persisted, fasting serum IRI was normal during several months, then became subnormal and the $\mathrm{I} / \mathrm{G}$ ratio was diminished further. Following glucose IV there was no change in serum IRI, no fall in NEFA and low glucose tolerance. The normally-occurring rises in serum IRI following arginine and glucagon IV and after the ingestion of a meal were absent. These permanently diabetic dogs were responsive to insulin IV. The insulin content of the pancreas was reduced to about $1.2 \%$ of the normal after 14 months of this diabetes. From the sequence of change it is concluded that growth hormone induced metasomatotrophic diabetes by causing excessive secretion of insulin under basal and stimulative conditions, leading to permanent loss of function of the beta cells of the pancreatic islets, to such an extent that basal insulin secretion was low and the ability to secrete extra insulin in response to stimuli was lost.
\end{abstract}

Key words: Growth hormone, somatotrophic diabetes, metasomatotrophic diabetes, hyperinsulinaemia, hypoinsulinaemia, insulin content of pancreas, insulin responses to glucose, glucagon, arginine, meals.
Metasomatotrophic diabetes is the permanent diabetes produced by the prolonged administration of growth hormone in intact dogs $[1,2,3]$ and in partially depancreatized dogs [4]. The close correspondence between the features of metasomatotrophic and of metahypophyseal diabetes $[5,6,7,8,9]$ indicates that growth hormone is the principal diabetogenic factor of the anterior pituitary gland in the dog [10]. These forms of diabetes have been attributed to severe deficiency of insulin, since they are associated, among other changes, with degeneration of the beta cells of the pancreatic islets $[9,11]$ and profound reduction in the insulin content of the pancreas [10]. Several investigators have proposed that the diabetes is produced by overactivity of the beta cells of the pancreatic islets, leading to loss of function and atrophy $[4,8,9,10]$.

We have investigated, therefore, insulin levels and insulin secretion in the somatotrophic diabetes that occurs during growth hormone administration and in the resulting metasomatotrophic diabetes, after the cessation of the treatment.

\section{Materials and Methods}

Adult male dogs of body weight $13-16 \mathrm{~kg}$ housed in metabolism
cages at $20-22{ }^{\circ} \mathrm{C}$ room temperature were fed daily with $425 \mathrm{~g}$ of
cooked meats (Romar 90 ) and $200 \mathrm{~g}$ of dog chow (Purina), divided
in two meals. This food contained about $140 \mathrm{~g}$ carbohydrate, $85 \mathrm{~g}$
protein and $27 \mathrm{~g}$ fat. Drinking water was always available. In the
control period of 4 months duration, the dogs became accustomed
to the laboratory conditions and the testing procedures. The tests
were performed as described previously [12] about $17 \mathrm{~h}$ after a
meal and were preceded by the withdrawal of two $6 \mathrm{ml}$ samples of
venous blood. Glucose $(1.0 \mathrm{~g} / \mathrm{kg}$ body weight) was given IV within
one minute, as a $50 \%$ solution (W/V) in 0.154 mol $\mathrm{NaCl} / 1$, after
allowing ample time for equilibration of the a and b anomers.
Arginine $(0.4 \mathrm{~g} / \mathrm{kg}$ body weight) ( $50 \% \mathrm{~W} / \mathrm{V}$ of L-arginine mono-
chloride in 0.154 mol NaCl/1) was injected IV within 2 min and
blood samples were taken at $5,10,15,30,60$ and $120 \mathrm{~min}$. Gluca-
gon, $0.1 \mathrm{mg} / \mathrm{kg}$ body weight (Lilly, Lot $258-234-\mathrm{B}-167-1$ in
$0.154 \mathrm{~mol} \mathrm{NaCl} / 1,10 \mathrm{mg} / \mathrm{ml}$ ) was injected IV within seconds:
blood samples were taken at $2,5,10,15,20,30,45$ and 

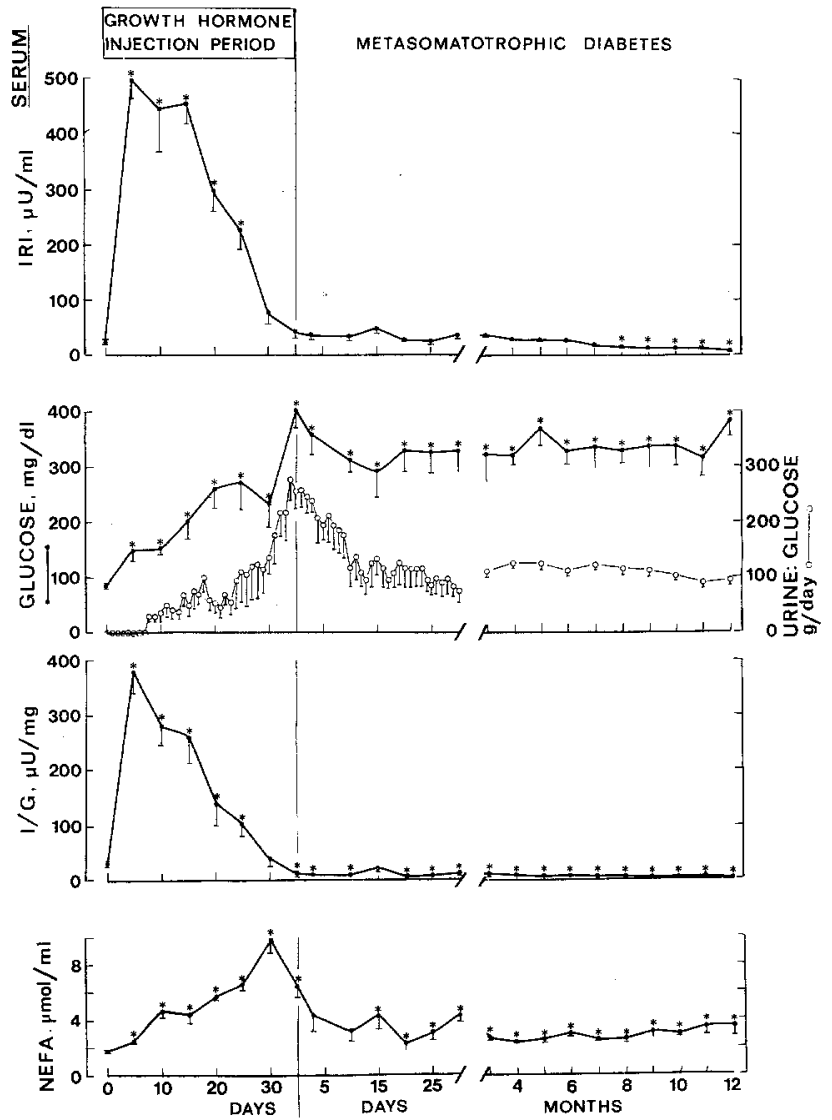

Fig. 1. Fasting levels of serum IRI, glucose, I/G ratio and NEFA and of urinary glucose excretion in 5 dogs when normal, during the daily injection of growth hormone for 32-44 days and in the metasomatotrophic diabetic state after the cessation of the growth hormone treatment. Values (mean \pm SEM) marked by asterisks are significantly different from the normal (pretreatment) values $(\mathrm{P}<0.050-<0.001)$

$60 \mathrm{~min}$. The test meal was the same as a usual meal: blood samples were taken at $15,30,60,120$, and $180 \mathrm{~min}$ from ingestion. Porcine insulin $(0.1 \mathrm{U} / \mathrm{kg}$ body weight) (Lilly, $1.0 \mathrm{U} / \mathrm{ml} \mathrm{in} 0.154 \mathrm{~mol}$ $\mathrm{NaCl} / \mathrm{l})$ was given IV, within seconds.

Bovine growth hormone (Connaught Medical Research Laboratories, Lot 100-1, dissolved in $0.154 \mathrm{~mol} \mathrm{NaCl} / \mathrm{l}$ at $\mathrm{pH} 8$, $10 \mathrm{mg} / \mathrm{ml}$ ) was injected subcutaneously, twice daily in 6 dogs. The initial dose was $2.0 \mathrm{mg} / \mathrm{kg} /$ day during the first 10-13 days and was then adjusted, according to the appearance in the dogs of severe diabetes or signs of remission, to the average of $2.6-3.3 \mathrm{mg} / \mathrm{kg} /$ day until the end of the treatment that lasted 32-44 days. One of these dogs was resistant to the diabetogenic effect of the growth hormone.

In serum, glucose was measured with glucose oxidase (Sigma No. 6125) and a polarographic electrode (Yellow Springs Instrument Co.) [13], non-esterified fatty acids (NEFA) were measured colorimetrically [14] and immunoreactive insulin (IRI) was assayed by a double antibody method [15]. Urine glucose was measured by Benedict's method and ketone bodies were estimated semiquantitatively [16]. At the end of the experiment, the dogs were anaesthetized with sodium pentobarbital IV $(25-30 \mathrm{mg} / \mathrm{kg}$ body weight) and blood was withdrawn through a carotid cannula prior to removal of the pancreas. The IRI of the pancreatic extract was determined $[12,17]$. Frozen sections of liver and other tissues were fixed and stained for lipid with Oil Red 0 dye [18]. Values are given as means $\pm \mathrm{SEM}$.

\section{Results}

\section{Induction of Diabetes}

Metabolic and hormonal changes during the induction and course of metasomatotrophic diabetes are shown in Figure 1. Within the first 15 days of growth hormone treatment, fasting serum glucose rose to about twice normal ( $85 \pm 5$ initially; $150 \pm 20$ at day 5 and $200 \pm 30 \mathrm{mg} / \mathrm{dl}$ at day 15). Increase in urine volume was followed at 5-8 days by sugar excretion, which continued to rise. Serum NEFA rose to about twice normal. Fasting serum IRI rose about 20 -fold $(24 \pm 4$ initially; $493 \pm 32$ at day 5 and $452 \pm$ $35 \mathrm{uU} / \mathrm{ml}$ at day 15$)$. The IRI/glucose (I/G) ratio rose about 10 -fold ( $30 \pm 5$ initially; $377 \pm 36$ at day 5 and $261 \pm 51 \mu \mathrm{U} / \mathrm{mg}$ at day 15). In the latter half of the growth hormone treatment (days 15 to 33-44 of injection) serum glucose continued to rise (to 400 $\pm 30 \mathrm{mg} / \mathrm{dl}$ ) and serum NEFA rose to about thrice normal. Mean sugar excretion daily per dog rose to a peak of about $250 \mathrm{~g}$ by the end of the treatment. Fasting serum IRI declined progressively from the high level to the near-normal level of $41 \pm 13 \mu \mathrm{U} / \mathrm{ml}$. The elevated $\mathrm{I} / \mathrm{G}$ ratio declined to normal, then to subnormal levels (11 $\pm 4 \mu \mathrm{U} / \mathrm{mg})$ (Fig. 1). At the end of the treatment, mean body weight was about $10 \%$ above the initial weight.

\section{Metasomatotrophic Diabetes}

In the first month of metasomatotrophic diabetes (beginning from the last injection of growth hormone), fasting serum IRI remained within the normal range $(24 \pm 6-46 \pm 8 \mu \mathrm{U} / \mathrm{ml})$, serum glucose remained elevated $(310 \pm 20-350 \pm 33 \mathrm{mg} / \mathrm{dl})$ and NEFA also remained high $(3-4 \mu \mathrm{mol} / \mathrm{ml})$. Mean sugar excretion declined from the very high value at the end of the growth hormone treatment to about $120 \mathrm{~g} /$ day (Fig. 1). After about 4 months of this diabetes, fasting serum IRI $(8 \pm 1-17 \pm 2 \mu \mathrm{U} / \mathrm{ml})$ was permanently below the control level and the $\mathrm{I} / \mathrm{G}$ ratio remained very low $(2-6 \mu \mathrm{U} / \mathrm{mg})$. Serum glucose was high $(311 \pm 30-380 \pm 26 \mathrm{mg} / \mathrm{dl})$, sugar excretion per dog was about $100 \mathrm{~g} /$ day and serum NEFA remained elevated $(2.73 \pm 0.26-3.50 \pm 0.61 \mu \mathrm{mol} /$ ml) (Fig. 1). The dogs deteriorated with the progression of metasomatotrophic diabetes. After 4 and 9 months, two of the five diabetic dogs were given insulin treatment (insulin-zinc, 24 and $50 \mathrm{U} /$ day, sub- 
cutaneously, in divided doses), which caused prompt improvement. The other three dogs were not given insulin treatment during the 14 months of this diabetes: their body weight declined gradually to $81 \%$ of the normal in this time.

\section{Response to Glucose}

The IV glucose load test was applied in the same dogs in the control period, and during and after the growth hormone treatment. In the normal state, glucose injection produced a 3 -fold rise in serum glucose ( 85 \pm 5 at $0 \mathrm{~min}$ and $290 \pm 23 \mathrm{mg} / \mathrm{dl}$ at $15 \mathrm{~min}$ ), a 5 -fold rise in serum IRI ( $24 \pm 3$ at $0 \mathrm{~min}$ and $128 \pm 14 \mu \mathrm{U} /$ $\mathrm{ml}$ at $15 \mathrm{~min}$ ) and a relatively small change in the $\mathrm{I} / \mathrm{G}$ ratio $(30 \pm 5$ at $0 \mathrm{~min}, 44 \pm 1.8$ at $15 \mathrm{~min}$ and $60 \pm$ $12 \mu \mathrm{U} / \mathrm{mg}$ at $60 \mathrm{~min}$ ) (Fig. 2 A). In this test after 8-9 days of growth hormone treatment, the rise in serum glucose was high and prolonged, the rise in serum IRI $(240 \mu \mathrm{U} / \mathrm{ml})$ over the high initial level was about twice the normal rise $(104 \mu \mathrm{U} / \mathrm{ml})$ and the $\mathrm{I} / \mathrm{G}$ ratio fell below the high initial value $(258 \pm 15$ at $0 \mathrm{~min}$ and $148 \pm 12-177 \pm 7 \mu \mathrm{U} / \mathrm{mg}$ at $15-$ $60 \mathrm{~min}$ ). On repetition of the test at 28-30 days of the growth hormone treatment, glucose tolerance was further depressed. Serum IRI (initially $78 \pm$ $25 \mu \mathrm{U} / \mathrm{ml}$ ) was unchanged, except for a decrease to $48 \pm 33 \mu \mathrm{U} / \mathrm{ml}$ at $60 \mathrm{~min}$ and the $\mathrm{I} / \mathrm{G}$ ratio decreased $(36 \pm 11$ at $0 \mathrm{~min}$ and $3 \pm 1-14 \pm 8 \mu \mathrm{U} / \mathrm{mg}$ at 15-60 min) (Fig. $2 \mathrm{~A}$ ).

In the glucose tolerance test applied at day 15 of metasomatotrophic diabetes, the rise in serum glucose was high and prolonged (Fig. 2 B). The initial serum IRI level $(46 \pm 8 \mu \mathrm{U} / \mathrm{ml})$ was near normal but no change occurred after the injection of the glucose load. At day 50 of metasomatotrophic diabetes, the result of the glucose load test was similar. Glucose tolerance was very low (serum glucose $324 \pm 30,621$ $\pm 25,558 \pm 21$ and $439 \pm 24 \mathrm{mg} / \mathrm{dl}$ at $0,15,30$ and $60 \mathrm{~min}$, respectively). The serum IRI level was unchanged $(36 \pm 5 \mu \mathrm{U} / \mathrm{ml}$ at $0 \mathrm{~min}$ and $31 \pm 4-41$ $\pm 5 \mu \mathrm{U} / \mathrm{ml}$ at $15-120 \mathrm{~min}$ ), and the initially low $\mathrm{I} / \mathrm{G}$ ratio $(12 \pm 3 \mu \mathrm{U} / \mathrm{mg}$ ) was further depressed (Fig. 2 B).

In the glucose tolerance test in normal dogs, NEFA fell to 65 and $71 \%$ of the initial value at 15 and $30 \mathrm{~min}(\mathrm{P}<0.010)$. In somatotrophic diabetic and in metasomatotrophic diabetic dogs, however, no change from the high initial values occurred during the test.

\section{Response to Arginine}

The injection of arginine $(0.4 \mathrm{~g} / \mathrm{kg}$ body weight IV) in 5 dogs at about day 20 of metasomatotrophic dia-
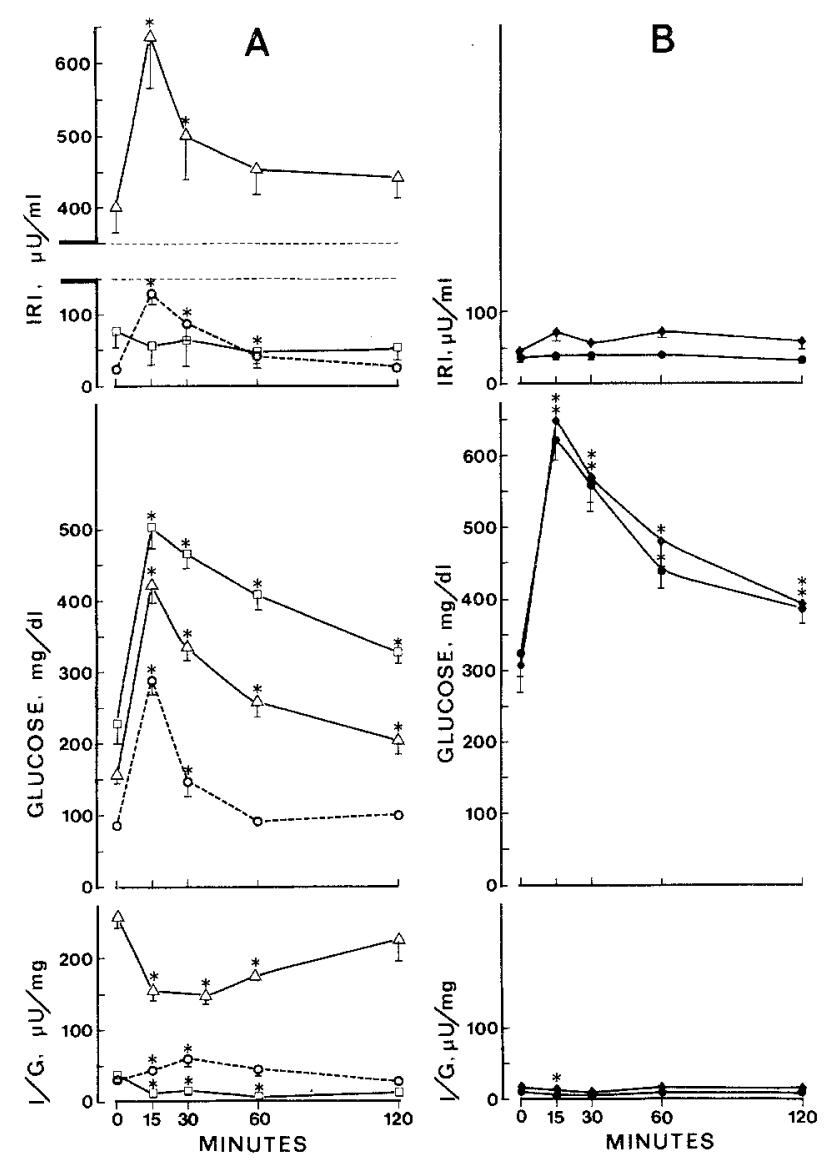

Fig. $2 \mathrm{~A}$ and B. Intravenous glucose tolerance before, during and after treatment of dogs with growth hormone. A Effects of glucose injection $(1.0 \mathrm{~g} / \mathrm{kg}$ body weight IV at time $0 \mathrm{~min})$ on serum IRI, glucose and $\mathrm{I} / \mathrm{G}$ ratio in 5 dogs when normal $\bigcirc-\ldots-\ldots$ and during the daily administration of growth hormone, at 8-9 days $\triangle \longrightarrow \triangle$ and at 28-31 days $\square-\square$. B Effects of the same glucose injection in these dogs when metasomatotrophic diabetic, at day $15 \longrightarrow$ and at day $50 \longrightarrow$ after the cessation of the growth hormone treatment. Values (means \pm SEM) marked by asterisks are significantly different from the initial (time 0 ) values $(\mathrm{P}<0.050-<0.001)$

betes produced no change in serum IRI from the fasting level during the 2 -hour test period ( $26 \pm 2$ at $0 \mathrm{~min}$ and $25 \pm 2-27 \pm 3 \mu \mathrm{U} / \mathrm{ml}$ at $5-120 \mathrm{~min}$ ). Serum glucose increased from the high initial level $(331 \pm 33$ at $0 \mathrm{~min}$ and $420 \pm 30-433 \pm 36 \mathrm{mg} / \mathrm{dl}$ at $10-15 \mathrm{~min})$, the $\mathrm{I} / \mathrm{G}$ ratio decreased $(9 \pm 1$ at $0 \mathrm{~min}$ and $6 \pm 1 \mu \mathrm{U} / \mathrm{mg}$ at 10 and $15 \mathrm{~min}$ ) and serum NEFA increased $(1.82 \pm 0.24$ at $0 \mathrm{~min}$ and $2.28 \pm$ $0.30-2.61 \pm 0.28 \mu \mathrm{mol} / \mathrm{ml}$ at $10-60 \mathrm{~min}$ ).

In this arginine test in normal dogs, as reported previously [12] serum IRI rapidly rose to over 4-fold and the $I / G$ ratio rose 3 -fold, with fractional rises in serum glucose and NEFA, of about $50 \%$. 


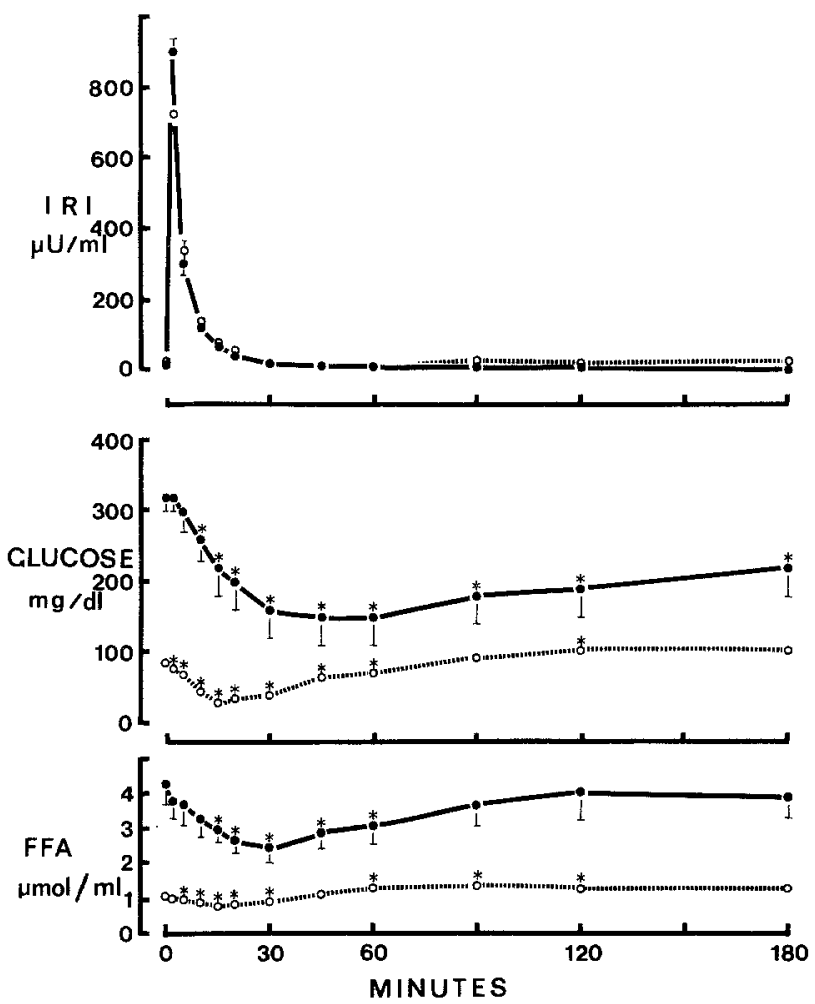

Fig. 3. Effects of insulin $(0.1 \mathrm{U} / \mathrm{kg}$ body weight IV at time $0 \mathrm{~min})$ on serum IRI, glucose, I/G ratio and NEFA at day 40 of metasomatotrophic diabetes in 5 dogs - and in 6 normal dogs O-----O. Values (means \pm SEM) marked by asterisks are significantly different from the initial $(0 \mathrm{~min})$ values $(\mathrm{P}<0.050-<0.001)$

\section{Response to Glucagon}

In metasomatotrophic diabetes of 60 days duration in 5 dogs, the injection of glucagon $(0.1 \mathrm{mg} / \mathrm{kg}$ body weight IV) produced no change in serum IRI from the fasting level during the 60 minute test period (17 \pm 1 at $0 \mathrm{~min}$ and $12 \pm 4-23 \pm 4 \mu \mathrm{U} / \mathrm{ml}$ during 2-60 min). Serum glucose rose from the high fasting level $(313 \pm 34$ at $0 \mathrm{~min}$ and $426 \pm 37-461 \pm$ $33 \mathrm{mg} / \mathrm{dl}$ at $10-60 \mathrm{~min})$. The $\mathrm{I} / \mathrm{G}$ ratio was initially low $(6 \pm 1 \mu \mathrm{U} / \mathrm{mg})$ and decreased at the $15-60 \mathrm{~min}$ intervals. Serum NEFA increased from the high initial level ( $3.30 \pm 0.60$ at $0 \mathrm{~min}$ and $4.40 \pm 0.30-$ $4.70 \pm 0.50 \mu \mathrm{mol} / \mathrm{ml}$ at $5-20 \mathrm{~min})$.

In this glucagon test in 6 normal dogs [12], serum IRI rose 8 -fold to a peak at $15 \mathrm{~min}$, serum glucose rose 3 -fold and the $\mathrm{I} / \mathrm{G}$ ratio rose over 2 -fold.

\section{Response to a Meal}

Following the ingestion of a meal in metasomatotrophic diabetes of about 30 days duration in 5 dogs, serum IRI was unaltered from the fasting value in the 3 -hour test period ( $26 \pm 5$ at $0 \mathrm{~min}$ and $22 \pm 4-26$ $\pm 8 \mu \mathrm{U} / \mathrm{ml}$ at $15-180 \mathrm{~min})$, except for a decrease to
$14 \pm 2 \mu \mathrm{U} / \mathrm{ml}$ at $120 \mathrm{~min}$. Serum glucose rose progressively over the high fasting value during the test $(319 \pm 14$ at $0 \mathrm{~min}$ and $361 \pm 24-503 \pm 28 \mathrm{mg} / \mathrm{dl}$ at $30-180 \mathrm{~min}$ ). The $\mathrm{I} / \mathrm{G}$ ratio was initially $8 \pm 2 \mu \mathrm{U} /$ $\mathrm{mg}$ and was unchanged, except for a decrease to $3 \pm$ $1 \mu \mathrm{U} / \mathrm{mg}$ at $120 \mathrm{~min}$. The NEFA value did not differ from the high initial value during the test period.

Following this meal in normal dogs [12], there were relatively small, but significant, increases in serum IRI, in serum glucose and in the $\mathrm{I} / \mathrm{G}$ ratio. The NEFA value was unchanged, except for a decrease at $60 \mathrm{~min}$.

\section{Response to Insulin}

In metasomatotrophic diabetic dogs after the injection of insulin $(0.1 \mathrm{U} / \mathrm{kg}$ body weight IV) there were marked and prolonged falls in serum glucose (321 \pm 19 at $0 \mathrm{~min}$ and $147 \pm 39 \mathrm{mg} / \mathrm{dl}$ at $15 \mathrm{~min}$ ) and in serum NEFA $(4.27 \pm 0.56$ at $0 \mathrm{~min}$ and $2.46 \pm$ $0.42 \mu \mathrm{mol} / \mathrm{ml}$ at $30 \mathrm{~min}$ ) from the high fasting levels (Fig. 3). In normal dogs after this injection of insulin, serum glucose fell $(86 \pm 4$ at $0 \mathrm{~min}$ and $30 \pm 5 \mathrm{mg} / \mathrm{dl}$ at $15 \mathrm{~min})$ then rebounded $(102 \pm 4 \mathrm{mg} / \mathrm{dl}$ at $120 \mathrm{~min}$ ), while NEFA also fell $(1.09 \pm 0.07$ at $0 \mathrm{~min}$ and $0.80 \pm 0.05 \mu \mathrm{mol} / \mathrm{ml}$ at $15 \mathrm{~min}$ ) then rebounded $(1.36 \pm 0.10 \mu \mathrm{mol} / \mathrm{ml}$ at $90 \mathrm{~min})$. These decreases in serum glucose and NEFA were of greater extent and duration in the metasomatotrophic diabetic than in the normal dogs. Following this injection of insulin, the disappearance of IRI from serum was rapid and similar in the diabetic and the normal dogs (Fig. 3).

\section{Insulin Content of the Pancreas}

In the 5 metasomatotrophic diabetic dogs, after 14 months of diabetes, the IRI extractable from the pancreas was $0.042 \pm 0.013 \mathrm{U} / \mathrm{g}$ pancreas or $0.087 \pm$ $0.028 \mathrm{U} / \mathrm{kg}$ body weight. This amount was only $1.2 \%$ of that reported in normal dogs, which was $3.66 \pm$ $0.50 \mathrm{U} / \mathrm{g}$ or $6.90 \pm 0.89 \mathrm{U} / \mathrm{kg}$ body weight $[12,19]$.

From visual comparison it was apparent that in the metasomatotrophic diabetic dogs the abdominal and subcutaneous adipose tissues were depleted of depot fat. The liver weight $(30.9 \pm 0.4 \mathrm{~g} / \mathrm{kg}$ body weight) was above the normal value of $25.4 \pm 1.4 \mathrm{~g} /$ $\mathrm{kg}$ body weight $[12,19]$. In stained sections of the liver, the frequency of intracellular fat droplets was normal or less, indicating relatively low fat content.

\section{Discussion}

A progression of change occurs during the production of metasomatotrophic diabetes. In a "prediabetic" stage of growth hormone treatment there are marked rises in serum IRI $[12,20]$ and plasma 
immunoreactive glucagon (IRG) $[21,22]$. In the following stage of early somatotrophic diabetes, the hyperinsulinaemia persists and the $\mathrm{I} / \mathrm{G}$ ratio remains elevated, despite the rise in serum glucose $[12,20]$. The elevation in blood insulin is due chiefly to increase in insulin secretion [23]. Two abnormalities in insulin receptors of circulating monocytes have been found in acromegaly, however, one being a decrease in receptor concentration per cell and the other an increase in receptor affinity [24].

The promtitude of the rises in glucagon and insulin in the circulation of the dog [21] and in the perfusate from the isolated pancreas [25], produced by growth hormone, is indicative of direct stimulation of the alpha and beta cells of the pancreatic islets. The rise in glucagon precedes the rise in insulin, however, glucagon does not appear to mediate the insulin, effect [26]. Changes in the concentrations of glucose and NEFA in blood do not appear to be of primary importance in the stimulation of insulin secretion early in the growth hormone treatment $[12,20,27]$. Insulin responses to the IV injection of glucose, glucagon and arginine, which signify rapid and transient rises in insulin secretion [28], are magnified in the prediabetic and early somatotrophic diabetic stages of growth hormone treatment [12].

A further stage of change is evident in the latter half of the growth hormone treatment, during which the severity of the diabetes increases, blood IRI declines to near-normal level, the $\mathrm{I} / \mathrm{G}$ ratio falls below normal and the insulin response to glucose decreases and finally disappears. It appears that active peptides derived from growth hormone in the body may be involved in the production of some of the hormonal and metabolic effects $[29,30]$.

The ultramicroscopic alterations in the beta cells of dog islets that occur during the induction and course of growth hormone diabetes are indicative of increased secretory activity, followed by degeneration [31]. The rat is resistant to the diabetogenic effects of growth hormone, but responds to the injected hormone [32] and to implanted pituitary tumour tissue $[33,34]$ with increase in insulin secretion and trophic alterations in the pancreatic islets. The insulin content of the pancreas decreases with the duration of growth hormone treatment in dogs $[12,22]$, indicating a higher rate of secretion than of replacement of insulin by synthesis. This sequence of changes, culminating in metasomatotrophic diabetes, indicates that growth hormone treatment causes excessive secretion of insulin under basal and stimulative conditions that results in degeneration of the beta cells, with severe loss of function. The fundamental nature of the action of growth hormone on the beta cells of the pancreatic islets is at present obscure.
Metahypophyseal diabetes $[5,7,8,9]$, and metasomatotrophic diabetes $[2,4,10]$ have been attributed to severe deficiency of insulin, a conclusion that is supported by the results of the present investigation. In the first four months of metasomatotrophic diabetes, fasting serum IRI was in the normal range and the $\mathrm{I} / \mathrm{G}$ ratio was low: subsequently, the IRI level became subnormal and the I/G ratio declined further. The basal systemic delivery rate of insulin was found to be depressed in this diabetes [35]. With the reduced rate of insulin secretion under fasting conditions, there was also failure to secrete insulin in response to a meal and to the infusion of glucose, glucagon and arginine. Metasomatotrophic diabetic dogs thus appear to be dependent on reduced basal secretion of insulin, without additional secretion in response to stimuli. The very low insulin content of the pancreas in conjunction with the reduced basal secretion of insulin indicates that the rate of synthesis of insulin is low. The indications are, therefore, that the beta cell damage results in deficient synthesis and deficient secretion of insulin.

A feature of this diabetes and also of metahypophyseal diabetes [36] is a marked responsiveness to the hypoglycaemic and NEFA-depressing effects of insulin. This sensitivity to insulin is probably an important factor in survival with only a limited basal secretion of insulin. The high NEFA level was indicative of continuously enhanced rate of mobilization of lipid: however, the depletion of depot fat in this prolonged diabetic state may have had the effect of limiting the quantity of fat mobilized from adipose tissue to the liver and other organs. Consequences of this limitation may have been the absence of marked fat accumulation in the liver and the preservation of sensitivity to insulin [37].

Acromegaly has characteristics that are qualitatively similar to the experimental effects of growth hormone [38, 39]. If acromegalic diabetes can be attributed to over-activity of growth hormone, it appears probable that stages comparable to those found in metasomatotrophic diabetes and its induction may occur in this disease. In the study of endocrine performance, measurements of hormonal levels in the steady state are required: the additional information on hormonal changes in response to stimulants of secretion provides further insight into endocrine function.

Acknowledgements. The investigation was supported by the Medical Research Council of Canada, Grant No. 1186, the J. P. Bickell Foundation and the Canadian Diabetic Association. Dr. J. Pierluissi was a fellow of CONICIT, Venezuela and was also supported by the Universidad Central de Venezuela. Dr. H. D. Bett provided a generous supply of growth hormone, Dr. Strath Wilson and Dr. A. M. Fisher gave antisera for insulin radioimmunoassay through their association with the Connaught Medical Research 
Laboratories and Dr. Mary A. Root of the Eli Lilly Laboratories gave glucagon and insulin. We are grateful for the assistance of Dr. Krishna Sudha Rastogi and Mr. G. R. Green in this investigation. Mr. W. D. Wilson, A. R. T., Hospital for Sick Children, performed the histological examinations.

\section{References}

1. Campbell J, Davidson I W F, Lei H P (1950) The production of permanent diabetes by highly purified growth hormone. Endocrinology 46: 588-590

2. Campbell J, Chaikof L, Davidson I W F (1954) Metahypophyseal diabetes produced by growth hormone. Endocrinology 54: $48-58$

3. Engerman RL, Davis MD, Bloodworth JMB Jr (1971) Retinopathy in experimental diabetes: its relevance to diabetic retinopathy in man. In: Diabetes. Excerpta Medica Int Congr Series 231: 261-267

4. Houssay B A, Rodriguez R R, Cardeza A F (1953) Accion diabetogena de la hormona de crecimento de la hipofisis. Rev Soc Argent Biol 29: 33-41

5. Young F G (1937) Permanent diabetes produced by pituitary (anterior lobe) injections. Lancet II: 372-374

6. Loubatières A (1939) Recherches sur la diabète surcé permanent consécutif aux injections d'extrait de lobe antérieur d'hypophyse chez le chien normal. CR Acad Sci [D] (Paris) 208: 1933-1935

7. Dohan F C, Lukens F D W (1939) Persistent diabetes following the injection of anterior pituitary extract. Am J Physiol 125: 188-195

8. Houssay B A, Foglia V G (1944) La diabetes metahipofisaria. Rev Soc Argent Biol 20: 247-259

9. Young FG (1949) The relationship of the anterior pituitary gland to diabetes mellitus. Acta Med Scand 135: 275-288

10. Campbell J (1955) Diabetogenic actions of growth hormone. In: Smith RW Jr, Gaebler OH, Long CNH (eds) The hypophyseal growth hormone, nature and actions. McGrawHill, New York, p 270-285

11. Richardson K C, Young FG (1938) Histology of diabetes induced in dogs by injection of anterior-pituitary extracts. Lancet I: 1098-1101

12. Campbell J, Pierluissi J, Green G R (1978) Somatotrophic diabetes: insulin release responses to arginine and glucagon in dogs. Diabetologia 15: 205-212

13. Okuda J, Okuda G (1969) A rapid polargraphic microdetermination of glucose with glucose oxidase. Clin Chim Acta 23: 365-367

14. Itaya K, Ui M (1965) Colorimetric determination of free fatty acids in biological fluids. J Lipid Res 6: 16-20

15. Hales CN, Randle PJ (1963) Immunoassay of insulin with insulin-antibody precipitate. Biochem J 88: 137-146

16. Dumm RM, Shipley RA (1946) The simple estimation of blood ketones in diabetic acidosis. J Lab Clin Med 31: $1162-1163$

17. Davoreen P R (1962) The isolation of insulin from a single cat pancreas. Biochim Biophys Acta 63: 150-153

18. Lillie RD (1965) Histological technique and practical histochemistry, 3 ed. McGraw-Hill, New York

19. Campbell J, Rastogi KS (1968) Elevation in serum insulin, albumin, and FFA with gains in liver lipid and protein induced by glucocorticoid treatment in dogs. Can J Physiol Pharmacol 46: $421-429$

20. Campbell J, Rastogi KS (1966) Growth hormone-induced diabetes and high levels of serum insulin in dogs. Diabetes 15 : $30-43$

21. Sirek A, Vranic M, Sirek OV (1977) Effect of a single somatotropin (STH) injection on plasma insulin and glucagon levels in the dog. Proc Int Union Physiol Sci 12: 701
22. Pierluissi J (1979) Insulin and glucagon levels in young dogs treated with growth hormone. In: Pierluissi J (ed) Endocrine pancreas and diabetes. Excerpta Medica Int Congr Series 459: 220-229

23. Campbell J, Rastogi K S (1969) Actions of growth hormone: enhancement of insulin utilization with inhibition of insulin effect on blood glucose in dogs. Metabolism 18: 930-944

24. Muggeo M, Bar R S, Roth J, Kahn C R, Gorden P (1979) The insulin resistance of acromegaly: evidence for two alterations in the insulin receptor on circulating monocytes. J Clin Endocrinol Metab 48: 17-25

25. Pek S, Tai T-Y, Crowther R, Fajans S S (1976) Glucagon release precedes insulin release in response to common secretagogues. Diabetes 25: 764-770

26. Tai T-Y, Pek S (1979) Direct stimulation by growth hormone of glucagon and insulin release from isolated rat pancreas. Endocrinology 99: 669-677

27. Pierluissi J, Oliviera A, de Maksimenko A, Espinosa I (1977) Effect of growth hormone on insulin secretion in young dogs. Proc Int Union Physiol Sci 13: 598

28. Campbell J, Rastogi K S (1966) Augmented insulin secretion due to growth hormone. Stimulating effects of glucose and food in dogs. Diabetes 15: 749-758

29. Kostyo J L: Search for the active site of growth hormone. In: James V H T (ed) Endocrinology, vol 2. Excerpta Medica Int Congr Series 403: 186-190

30. Lewis U J, Singh R N P, Vanderlaan W P, Tutwiler G F (1977) Enhancement of the hyperglycemic activity of human growth hormone by enzymic modification. Endocrinology 101: $1587-1603$

31. Volk B W, Lazarus S S (1962) Ultramicroscopy of dog islets in growth hormone diabetes. Diabetes 11: 420-435

32. Malaisse W J, Malaisse-Lagae F, King S, Wright F H (1968) Effect of growth hormone on insulin secretion. Am J Physiol 215: $423-428$

33. Martin J H, Åkerblom H K, Garay G (1968) Insulin secretion in rats with elevated levels of circulating growth hormone due to MtT-W15 tumor. Diabetes 17: 661-667

34. Bencosme S A, Tsutsumi V, Martin J M, Åkerblom H K (1971) Ultrastructural changes in B cells of pancreatic islets from rats with elevated levels of circulating growth hormone secreted by MtT-W15 tumor. Diabetes 20: 15-26

35. Pierluissi J, Norwich K H, Green G R, Campbell J (1978) Insulin kinetics in metasomatotrophic diabetes. Metabolism 27: 61-70

36. Marks H P, Young F G (1939) Observations on the metabolism of dogs made permanently diabetic by treatment with anterior pituitary extract. J Endocrinol 1: 470-510

37. Randle P J (1977) Protein phosphorylation and dephosphorylation and insulin action. In: Bajaj J S (ed) Diabetes. Excerpta Medica Int Congr Series 413: 169-179

38. Luft R, Cerasi E, Hausberger C A (1967) Studies on the pathogenesis of diabetes in acromegaly. Acta Endocrinol (Kbh) 56: 593-607

39. Fineberg S E, Merimee T J, Rabinowitz D, Edgar P J (1970) Insulin secretion in acromegaly. J Clin Endocrinol 30: 288-292

Received: January 19, 1979,

in revised form: October 1,1979

Prof. J. Campbell

Department of Physiology

Medical Sciences Building

University of Toronto

Toronto, Ontario

Canada M5S $1 \mathrm{~A} 8$ 